\title{
Snapshot of REDD+ in Papua New Guinea
}

Andrea Babon

\section{Key points}

- Papua New Guinea has been a leading proponent of REDD+ at the international level. However, poor governance conditions in the country have frustrated efforts to create an enabling environment for REDD+ and progress in readiness activities has been slow.

- A recent study measuring forest cover change in Papua New Guinea during 1972-2002 found an annual combined rate of deforestation and forest degradation of 1.41\%, higher than previously thought. Commercial logging (48.2\%) and subsistence agriculture (45.6\%) were the leading drivers of forest cover change during this period, with forest fires (4.4\%), clearing for agricultural plantations (1.0\%) and mining (0.6\%) only minor contributors.

- Papua New Guinea is unique amongst REDD+ countries in that the vast majority of land (97\%) is held under customary ownership by kinship groups, not by the state. Customary landowners ${ }^{2}$ interviewed have said they are unlikely to participate in REDD+ unless they receive a majority of the benefits. Without the involvement of customary landholders, beginning at the community level with sustainable land use planning, effective, efficient and equitable REDD+ is unlikely and the permanence of emission reductions is tenuous. Papua New Guinea's logging industry has been subject to chronic allegations of illegal and unsustainable logging practices for decades. Current proposals for REDD+ do not consider a moratorium on new logging concessions, but instead promote reduced impact logging and improved management of secondary forests as the best way to implement REDD+.

- The government of Papua New Guinea has received substantial criticism about a lack of stakeholder and community consultation in REDD+ policy development. Consultants from outside the country have developed several key REDD+ documents without adequate processes to consult, share information or promote stakeholder buy-in. This has led to a lack of national ownership of REDD+ strategies, including within implementing agencies.

- Without major governance and institutional reforms capable of getting the machinery of government moving in the same direction, effective, efficient and equitable REDD+ in Papua New Guinea is uncertain.

\section{Introduction}

Papua New Guinea houses the third largest tract of intact tropical forest in the world. However, the country's forests face a number of threats. Carbon emissions from land use, land use change and forestry (LULUCF) are estimated at 110-126 Mt CO²e, making the country one of the highest per capita emitters in the world (OCCD 2011). Prime Minister Sir Michael Somare has been a leading proponent of an international regime for reducing emissions from deforestation and forest degradation and enhancement of forest carbon stocks (REDD+) as part of the United Nations Framework Convention on Climate Change (UNFCCC). However, domestic conditions have frustrated efforts to create an enabling environment for REDD+, and the progress of readiness ${ }^{3}$ activities and pilot projects has been slow. This snapshot aims to provide a brief overview of the context for REDD+ in Papua New Guinea, the evolution of REDD+ to date, and key issues moving forward.

\section{Context for REDD+ in Papua New Guinea}

Papua New Guinea is a country of enormous diversity geographically, biologically, socially, culturally, politically and economically. Its 6.6 million people speak more than 800 languages. The majority of people live in rural communities based on a traditional village structure; only about 13\% of the population live in urban areas (AusAID 2010a). The country has a small dual economy. Large-scale non-renewable extractive industries-mainly minerals, oil and gas - provide a large proportion of government revenue. The rural economy supports about $80 \%$ of the population through semi-subsistence agriculture (AusAID 2010a). Despite considerable revenue from mining, the government struggles to provide basic services and infrastructure for its people (Allen and Hasnain 2010). In 2008, Papua New Guinea ranked 149 out of 179 countries in the Human Development Index published by the United Nations Development Program. Social indicators are 
No. 40

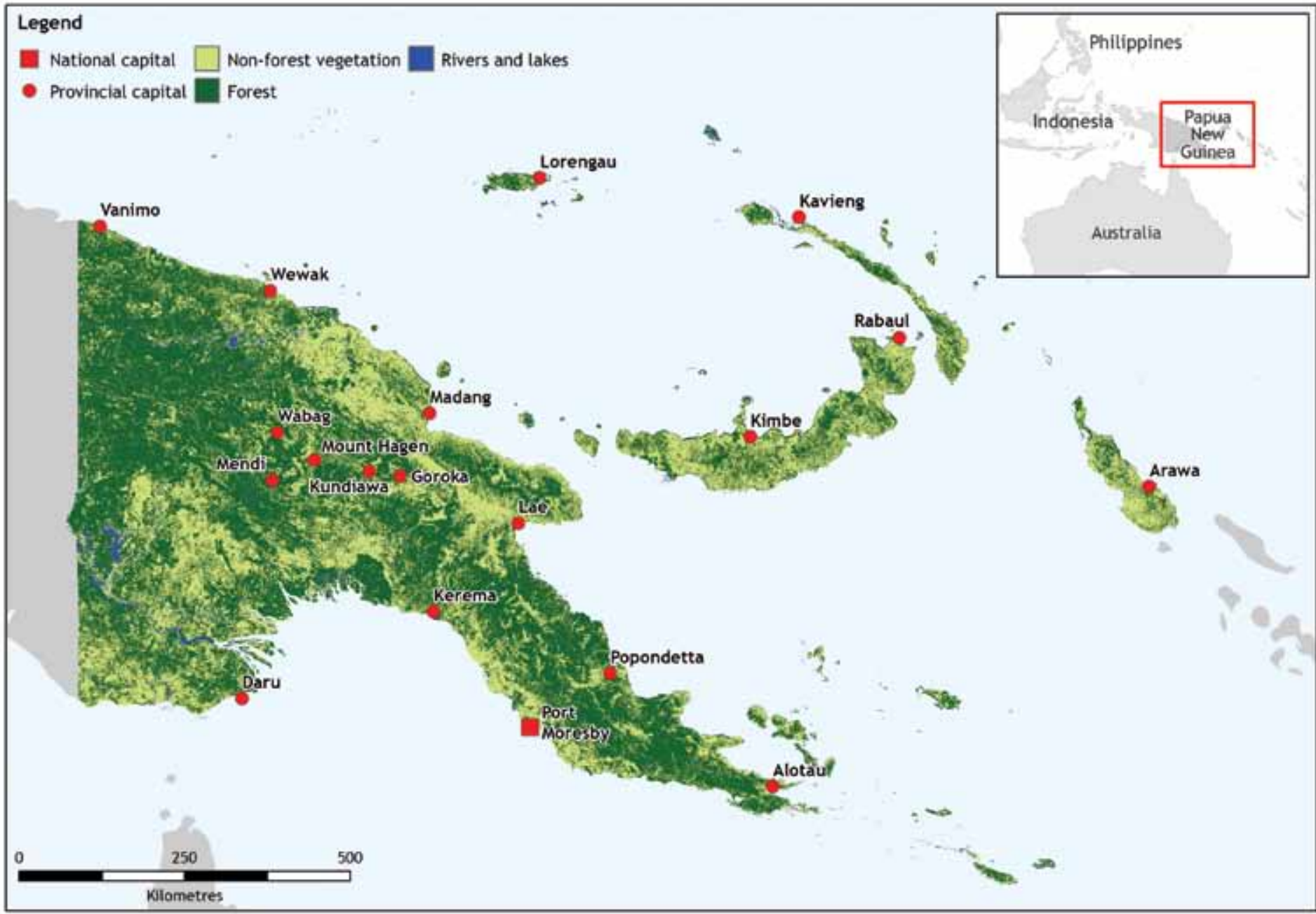

\section{Figure 1. Map of Papua New Guinea showing forest cover and main cities}

among the lowest in the Asia-Pacific region, including educational attainment, life expectancy and maternal and child mortality rates (AusAID 2010a). This is partly seen as a result of widespread corruption, weak performance of public services, and law and order problems (AusAID 2010a). In 2010, Papua New Guinea ranked 154 out of 178 countries in the 'Corruption Perception Index' ${ }^{\prime 4}$ which ranks countries in the degree to which corruption is perceived to exist among public officials and politicians (Transparency International 2010). In addition to the general socio-economic and political context, 3 key factors can affect the development of REDD+ in the country: drivers of deforestation, forest governance and land tenure.

\subsection{Drivers of deforestation}

A recent study measuring forest cover change in Papua New Guinea during 1972-2002, using high-resolution wallto-wall satellite imagery, found an annual combined rate of deforestation and forest degradation of 1.41\% (Shearman et al. 2009). The study also identified commercial logging (48.2\%) and subsistence agriculture (45.6\%) as the leading drivers of forest cover change during this period, with forest fires (4.4\%), clearing for agricultural plantations (1.0\%) and mining (0.6) only minor contributors (Figure 2). Logging was the main driver of forest cover change in the lowland areas of the coastal and island regions, with subsistence agriculture the major driver in the highland areas (Shearman and Bryan 2011). Rapid population growth, international demand for timber and weak governance are seen as indirect drivers of deforestation.

\subsubsection{Commercial logging}

The contribution of forestry to the national economy has dominated forest management in recent decades. Timber is the third largest foreign exchange earner after mineral and agricultural exports (ODI 2007b). The forestry industry is largely based on the extraction of round logs for export, with little downstream processing (ODI 2007b). The timber industry is dominated by a few foreign-owned logging companies that have been subject to persistent reports of illegal and unsustainable logging practices, political corruption, human rights abuses and a lack of sustained benefits for local communities (ODI 2007b). There is general agreement that current rates of commercial timber harvesting are unsustainable (Shearman et al. 2009; Fox et al. 2010). 


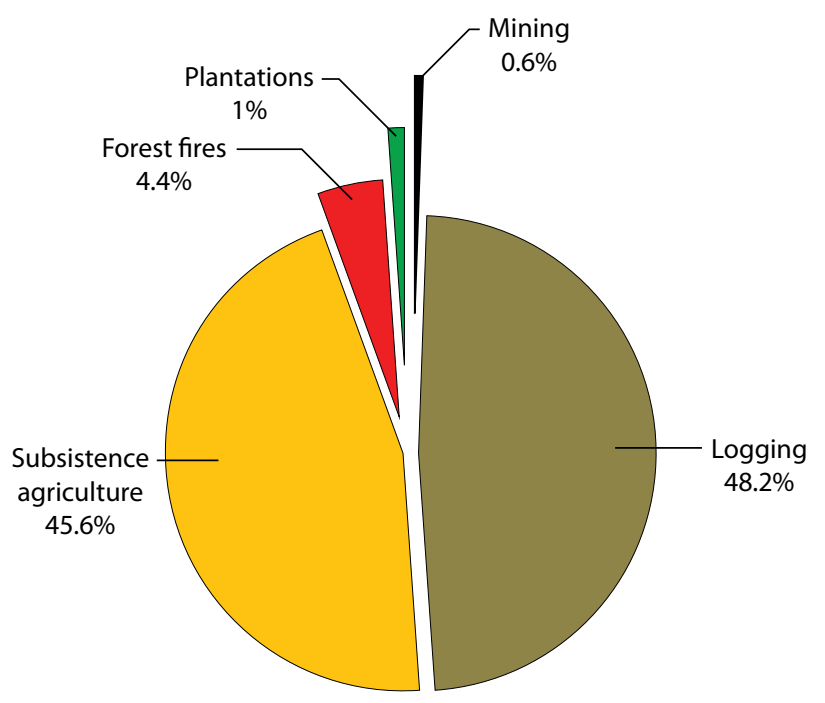

Figure 2. Drivers of forest change in Papua New Guinea 1972-2002

Source: Shearman et al. (2008)

\subsubsection{Subsistence agriculture}

Approximately $80 \%$ of the population depends on subsistence agriculture for food. People practice a traditional system of shifting cultivation whereby patches of forest are cleared and planted as food gardens for several crop cycles and then left fallow for long periods during which the forest regenerates. Wherever the population is sparse, gardens remain isolated and revert to forest after cultivation ceases (Marsden et al. 2006, in Shearman et al. 2008). However, rapid population growth has increased the demand for food and saleable produce from gardens. A recent study of forest change in Papua New Guinea found substantial net deforestation occurring as a result of expansion of the area of food gardens as well as intensification of agriculture within existing gardens (Shearman et al. 2009). This deforestation was strongly related to population density.

\subsubsection{Commercial agriculture}

Whilst forest clearing for agricultural plantations was only a minor driver of deforestation from 1972 to 2002 (Shearman et al. 2009), commercial plantations, particularly oil palm, have been expanding ever since. The government plans for substantial growth in production of the country's four major export crops (palm oil, coffee, cocoa and copra) over the next 20 years, with the area under oil palm alone estimated to grow by 5-6\% annually (GoPNG 2010). Since 2003, there has been a rapid increase in the number of special agriculture and business leases (SABLs) granted by the government over large areas of land (sometimes in excess of 100000 ha) for 'agroforestry' projects. SABL's are now thought to cover about 5.2 million hectares and there is concern that many of these projects may merely be logging projects disguised as largescale agricultural projects or land speculation (Filer 2011). Hence clearing for, or under the guise of, agricultural plantations may become a more significant driver of deforestation in the future.

\subsection{Forest governance}

There have been several inquiries into persistent claims of poor forest governance in Papua New Guinea over the past 25 years. These include the Barnett Inquiry, which looked into aspects of the timber industry in 1987 (GoPNG 1989), and an independent forest review carried out between 2001 and 2005 as a condition of the World Bank's Forest and Conservation Project (FCP) loan (Forest Trends 2006). However, few meaningful or long-lasting reforms came out of these efforts (ODI 2007a). This is despite significant international assistance to the forest sector, including World Bank support for the development of a Tropical Forestry Action Plan in 1990, and the Forestry and Conservation Project which commenced in 2001. In 2003, the World Bank suspended the US\$17 million FCP loan, which had included a series of reform conditions, due to dissatisfaction with the government's efforts to curb illegal logging. In May 2005, the loan was cancelled altogether with no significant reform outcomes (World Bank 2006). In 2007 a review by the International Tropical Timber Organisation found that the government and the forestry industry could not demonstrate sustainable forest management, concluding that, whereas Papua New Guinea's forest laws are generally strong, the government lacked capacity and willingness to enforce these laws (ITTO 2007). This recent history of failed reforms and the persistence of illegal logging serve to highlight the significant governance challenges Papua New Guinea is likely to face if it is to build an enabling environment for effective and equitable REDD+ (ODI 2007a).

\subsection{Land tenure}

Customary land tenure is enshrined in the country's constitution; Papua New Guineans retain customary ownership over 97\% of the country (ODI 2007a). Customary landowners have full exploitation rights to the trees and other forest resources on their land. However, customary landowners cannot sell their land. Instead, landowners of a particular area can form a separate entity known as an Incorporated Land Group (ILG) which can enter into an agreement with the state to lease land or grant specific rights (ITTO 2007). In turn, the state can negotiate an agreement with potential developers of logging projects, agricultural plantations or mines. Logging activities also require negotiation of a Forest Management Agreement between the identified ILGS of the potential forest area and the relevant authority, the Papua New Guinea Forest Authority (PNGFA). A Forest Management Agreement enables the ILGs to give their consent to the Forest Authority to manage their forest; The Forest Authority agrees to manage the landowner's forest through various stages of development. Although this process must be done with the informed consent of customary landowners, in practice the process can be abused. In almost all cases, proper consent has not been secured or due process has not been followed (ODI 2007a; ITTO 2007; Forest Trends 2006).

In addition, in May 2010 the Parliament of Papua New Guinea passed a controversial amendment to the Environment Act of 2000, restricting landowners' rights if a project on their land is ruled to be of 'national interest'. This amendment has been 
widely condemned as unconstitutional and is seen as potentially weakening landowners' rights with respect to REDD+ (Lang 2010). It is widely felt that land use planning at the community level is an essential first step for the implementation of REDD+ since customary landowners, rather than the state, own the vast majority of forest resources (INA and IGES 2010). Effective processes for social mapping, boundary demarcation, ILG formation, and participatory decision making are likely to be lengthy and onerous, but vital for effective and equitable REDD+.

\section{Evolution of REDD+ in Papua New Guinea}

As a founding member of the Coalition for Rainforest Nations (CfRN) in 2005, Papua New Guinea has advocated for the inclusion of REDD+ under the UNFCCC. It supports a phased approach to allow for different degrees of REDD+ readiness amongst implementing countries. According to the CfRN proposal:

Phase I would primarily use new and additional Overseas Development Assistance to strengthen capacity and support demonstration activities; Phase II could be funded by revenues generated from the auction of AAUs [assigned amount units] and carbon taxes within Annex I countries and would support the scaling-up of demonstration activities; and Phase III would use global carbon market funds that could be supported by the auction of AAUs and carbon taxes to finance REDD. (GCP 2008)

\subsection{Institutional arrangements}

In October 2008 the Office of Climate Change and Carbon Trade (OCCCT) was established and tasked with developing Papua New Guinea's climate change policy and managing carbon trading. The OCCCT sat under the prime minister's office, with a former adviser to the prime minister appointed as executive director. In early 2009, the body was renamed the Office of Climate Change and Environmental Sustainability (OCCES), and was plagued by a number of scandals, including questions regarding its legality and allegations of corruption and financial mismanagement against the executive director (Wynn and Creagh 2009). In June 2009, the executive director was suspended and a review ordered (Somare 2009). The former executive director is now imprisoned, charged with the February 2011 murder of a high-profile former rugby player. These scandals have significantly affected the legitimacy and trust in climate change institutions, both domestically and internationally, and raised serious concerns about nepotism in appointments to key climate change policy positions.

In early 2010, a series of decisions by Papua New Guinea's National Executive Council abolished OCCES and established a new governance structure to coordinate action on climate change (OCCD 2011). A whole-of-government National Climate Change Committee was established as the main decision-making body for climate change policy. This essentially broadened oversight of climate change policy from the prime minister's office to a committee comprising the Secretaries of all key government departments. The newly formed Office of Climate Change and Development (OCCD) was established as the main coordinating body for climate change policy (OCCD 2011). A Technical Working Group on REDD+ has also been convened with diverse membership:

- Government agencies including the Department of Environment and Conservation and the Papua New Guinea Forest Authority;

- Government advisers including the consulting firm McKinsey and Co.;

- Nongovernmental organisations including WWF, The Nature Conservancy, and the Papua New Guinea Eco-Forestry Forum (an umbrella organisation representing a number of NGO's involved in promoting sustainable forest management);

- Donors including UN-REDD, the Forest Carbon Partnership Facility, AusAID, JICA and the European Union; and

- Industry associations including the Forest Industries Association of Papua New Guinea.

Even though the OCCD is nominally leading REDD+ readiness activities, the organisational instability of the previous incarnations of the OCCD and a lack of capacity, resources and coordination between it and the Papua New Guinea Forest Authority and the Department of Environment and Conservation have led to lengthy delays in the development of a REDD+ policy framework and associated legislation. The consulting firm McKinsey and Co. is driving the development of several key REDD+ documents, including the Climate Compatible Development Strategy and the most recent UN-REDD Papua New Guinea National Programme proposal.

\subsection{Policy development}

Several government agencies have produced policy documents related to climate change and REDD+. These include a rather brief national climate change policy framework for Papua New Guinea, developed by the former Office of Climate Change and Environmental Sustainability (OCCES undated); and the forestry and climate change framework for action 2009-2015 (Ministry of Forests 2009). In the lead-up to the 15th Conference of the Parties to the UNFCCC in Copenhagen in December 2009, McKinsey and Co. was engaged to draft a national climate change and REDD plan that could be used as part of the negotiations. The process for developing this plan was criticised for its lack of stakeholder consultation and national ownership.

In March 2010 the government released the McKinsey-driven draft 'Climate-Compatible Development Strategy' for public comment. The strategy notes an aspirational goal of carbon neutrality by 2050 whilst still achieving annual economic growth of $7 \%$. This strategy suggests that the government expects REDD+ to be a significant contributor to its emissions reduction and economic growth goals over the next 20 years (GoPNG 2010). The strategy does not suggest a complete halt in commercial logging, rather it identifies reduced impact logging, secondary forest management and improved management of secondary forests as providing the greatest opportunities for REDD+. The strategy largely ignores opportunities for reducing forest loss caused by subsistence 
agriculture thereby setting aside the difficulties of effecting change in agricultural practices. The strategy prioritises the development of a monitoring, reporting and verification (MRV) system along with fund disbursement mechanisms and benefitsharing models. Importantly, it acknowledges current capacity limitations, and notes that the policy frameworks, institutional structures and capacity for achieving the strategy's vision are currently insufficient. An interim action plan for the Climate Compatible Development Strategy released in August 2010 lists capacity development as a key priority for the next 3 years, although this is largely in relation to the capacity of the OCCD, rather than broader capacity development within the country.

The Climate Compatible Development Strategy was completed prior to the 16th Conference of the Parties to the UNFCCC in Cancún in December 2010; ad is being developed into a national policy and supporting legislation; and is due to be presented to the parliament by the end of 2011. As with many other aspects of REDD+ policy development in the country, this strategy has faced many implementation delays. These include the development of a benefit-sharing model, which was meant to be undertaken in 2010, and which some observers fear may not be completed in time for inclusion in REDD+ legislation. There has also been criticism of a lack of consultation during the drafting process for the REDD+ policy and legislation.

\subsection{Demonstration activities}

Several REDD+ demonstration activities ${ }^{5}$ are being planned in Papua New Guinea.

- $\quad$ The Papua New Guinea Forest Authority has identified 4 provinces suitable for REDD+ demonstration activities based on sustainable forest management (GoPNG 2010):

$$
\begin{aligned}
& \text { Milne Bay } \\
& \text { Sandaun } \\
& \text { Eastern Highlands } \\
& \text { West New Britain }
\end{aligned}
$$

- The Australian government provided grants of up to AU\$200 000 in 2010 to 4 NGOs to develop REDD+ demonstration activity concepts in 5 provinces (AusAID 2010b):

- The Nature Conservancy in the Adelbert Mountains, Madang Province

- Wildlife Conservation Society in New Ireland and Manus provinces

Conservation International in the Yus area of Morobe province

Live and Learn in West New Britain Province

- A local NGO, FORCERT, is coordinating a trial Payment for Environmental Services (PES) project. FORCERT is working at the community level, to develop a forest carbon inventory methodology and pilot project, and at the national level, to develop a proposed PES framework whose main elements should provide guidelines for REDD+ and PES policy and legislation.
- Media reports suggest that private sector carbon brokers are operating in the country and trying to secure agreements with landowners to develop REDD+ projects for the voluntary carbon market (Gridneff 2009a, 2009b). This is taking place despite the government's opposition to the voluntary carbon market (DEC 2009).

- In July 2010, two projects submitted Project Design Documents for validation under the Climate, Community and Biodiversity standards (CCBA 2010a):

- April Salumei Sustainable Forest Management Project, East Sepik (April Salumei Foundation- and Rainforest Management Alliance).

Kamula Doso Improved Forest Management Carbon Project, Middle Fly District (Tumu Timbers Development).

Both the April Salumei and Kamula Doso projects are located in existing logging concessions and are controversial. The CCBA received many public comments critical of the two projects, including a legal opinion sought by the government 'which shows [the projects] to be incompatible with existing PNG laws and regulations' (CCBA 2010b). Meanwhile, the April Salumei site has now been included as one of the Papua New Guinea Forest Authority's official REDD+ demonstration sites and is going through a community consultation process in an effort to secure free, prior and informed consent from landowners.

\subsection{Donors}

The government has estimated that REDD readiness activities could cost US\$30-50 million over the next 5 years (GoPNG 2010). Several multilateral and bilateral organisations are supporting REDD+ readiness development.

Forest and Carbon Partnership Facility (FCPF). Papua New Guinea submitted a Readiness Plan Idea Note in 2008 but, as of May 2011, had not submitted a Readiness Plan Proposal.

\section{UN Collaborative Programme on Reducing Emissions from Deforestation and Forest Degradation in Developing Countries (UN-REDD). Papua New Guinea developed a National} Joint Programme proposal to participate in UN-REDD in 2009. However, this initial US\$2.58 million programme was never implemented. A programme review in October 2010 highlighted several implementation issues, including stakeholder engagement, access to data, carbon measurement and monitoring, legal uncertainty and policy inconsistency (Chatterton 2010). Despite these concerns, a second PNG National Programme was developed and provisionally approved, subject to 16 conditions, by the UN-REDD policy board in November 2010. This US\$6.4 million programme has a strong focus on monitoring, reporting and verification, but has again faced criticism about a lack of stakeholder consultation (PNGEFF 2010).

Australian Agency for International Development (AusAID). As part of their International Forest Carbon Initiative, the Australian government is providing support to Papua New Guinea for 
the design of a national carbon measurement system, and other assistance. This programme has also faced delays due to governance concerns and a lack of progress on performance measures (Chatterton 2010).

Japan International Cooperation Agency (JICA). JICA is supporting the Papua New Guinea Forest Authority to improve its remote sensing and GIS capabilities as part of its Forestry Preservation Program, which commenced in March 2010. The JICA assistance will be closely coordinated with the UN-REDD programme components focused on MRV.

European Union (EU). The EU is currently funding a few small forestry-related activities, including supporting the Papua New Guinea Forest Authority in forest inventory techniques and mapping. The EU is likely to fund some REDD+ related activities in 2011, including contributing to remote sensing of forest degradation.

\section{Key issues}

Several key issues need to be addressed for Papua New Guinea to move forward with REDD+, including governance, MRV systems, and stakeholder participation, as outlined below:

\subsection{Governance}

The evolution of REDD+ in the country has been plagued by a string of scandals, including allegations of corruption, nepotism and dishonest conduct amongst various actors taking advantage of the current policy vacuum and general poor governance (for example, see Arek 2009; Wynn and Creagh 2009). The media has reported on so-called 'carbon cowboys' roaming the countryside, convincing landowners to sign agreements handing over carbon rights (Gridneff 2009a). Scandals also plagued the former national climate change office, the OCCES; its former director was suspended in July 2009 pending an investigation for reported selling of fake carbon credits to an Australian carbon trader, as well as financial irregularities (Gridneff 2009b). A broad programme of institutional reform and advances in good governance are likely to be a necessary precondition if Papua New Guinea is to receive further investment in REDD+ from the international community. At this stage, it is fair to say that REDD+ investment in Papua New Guinea poses a significant risk for both the private sector and donor community.

\subsection{Monitoring, reporting and verification}

Papua New Guinea is a large and geographically complex country with highly diverse forests and the government has limited capacity and resources to update forest data. Even though there is some uncertainty and debate regarding forest cover, rates of deforestation and forest degradation, and forest carbon dynamics, in-country capacities such as the Remote Sensing Unit at the University of Papua New Guinea are providing technical support services to the Forest Authority and other parts of the government in terms of updating data and improving methodologies.

Donors such as the UN-REDD program, JICA and AusAID are also providing support for the country to develop its MRV capabilities. However, these efforts are largely focussed on building capacity at the national level and more attention will be needed to enable maximum involvement of landholding communities in activities such as ground verification. A number of challenges remain in developing a rigorous MRV system in Papua New Guinea-as they do in other parts of the world-and significant investments in both human and technical capacity at all levels will be needed (Shearman et al. 2009; Howes 2009; Filer et al. 2009; Shearman et al. 2010; PNGFA 2011).

\subsection{Stakeholder participation}

National stakeholders and international institutions have criticised the lack of stakeholder participation in REDD+ activities to date. An external review of Papua New Guinea's proposal to the Forest Carbon Partnership Facility noted that 'neither the forest owners, NGO's or private sector representatives have been involved in the R-PIN [Readiness Plan Idea Note]' (Anonymous 2008). Chatterton (2010) made similar comments in a review of the UN-REDD National Joint Programme. Concerns have been expressed about the government's position on stakeholder participation in its role as co-chair of the REDD+ Partnership ${ }^{6}$, an interim platform that has been heavily criticised for preventing civil society groups from participating in its meetings (Lang 2010). There is also widespread concern that insufficient attention has been paid to awareness raising, information sharing and capacity building among customary landowners to enable them, as resource owners, to participate in a meaningful way in REDD+ readiness activities. The government will need to demonstrate stronger commitment to stakeholder participation in all stages of REDD+ design and implementation if it is to achieve effective and equitable REDD+.

\section{Conclusion}

Despite Papua New Guinea's prominent role as a lead proponent of REDD+ in international climate change negotiations, domestic progress toward creating an enabling environment for REDD+ has been slow. The country faces a number of governance challenges that have eluded easy solutions in the past. Realising the potential for REDD+ is likely to become mired in these same challenges, despite professed political will and apparent leadership of Papua New Guinea on the international REDD+ stage. Whilst a number of donors are providing support for REDD+ readiness, many of these initiatives have faced significant obstacles and delays. In short, capacity and resource constraints within government agencies, a lack of interagency coordination, corruption and political interference, limited commitment to stakeholder engagement, MRV capacity constraints and the persistent inability to tackle the drivers of deforestation suggest that effective, efficient and equitable REDD+ in Papua New Guinea may be a long way off. 


\section{Endnotes}

1 PhD candidate at the School for Environmental Research, Charles Darwin University, Australia. The author can be contacted at: andrea.babon@students.cdu.edu.au.

2 The term 'landowners' in Papua New Guinea is used to describe groups or individuals with customary rights to land and resources. The term covers resource rights as well as land rights, and masks the distinction between group ownership rights and individual use rights (Fingleton 1993: 43, cited in Taylor 1997).

3 Readiness activities include developing national policies and strategies for REDD+; building human, institutional and technical capacity; developing emissions baselines and business-as-usual scenarios; designing monitoring, reporting and verification systems, etc.

4 The score of 178 is the most corrupt ranking on the Corruption Perception Index.

5 In this context, the term 'demonstration activities' refers to site-specific projects designed to test mechanisms for REDD+. Key activities may include 'the promotion of more sustainable forest management practices (e.g. reduced impact logging), forest conservation combined with incentive payment schemes, and monitoring systems that measure the change in carbon stocks and fluxes' (Wertz-Kanounnikoff and KongphanApriak 2009).

6 The REDD+ Partnership was launched in May 2010 as an interim platform for interested governments to scale up REDD+ actions and finance. The Partnership is considered interim as it will be incorporated into any future UNFCCC REDD+ mechanism.

\section{References}

Allen, M. and Hasnain, Z. 2010 Power, pork and political patronage: decentralisation and the politicisation of the development budget in Papua New Guinea. Commonwealth Journal of Local Governance 6: 7-31.

Anonymous 2008 Forest Carbon Partnership Facility, Readiness Plan Idea Note: external review (PNG). http://www.forestcarbon partnership.org/fcp (30 June 2010).

Arek, M. 2009 Climate change boss admits to failure. The National, 20 February 2009.

Australian Agency for International Development (AusAID) 2010a About Papua New Guinea. http://www.ausaid.gov.au/country/ png/png_intro.cfm (1 August 2010).

Australian Agency for International Development (AusAID) 2010b Forest Carbon Initiative concept development grants. http:// www.ausaid.gov.au/keyaid/forest-carbon.cfm (21 July 2010).

Chatterton, P. 2010 Review of the UN-REDD joint programme in Papua New Guinea. http://www.un-redd.org/Portals/15/ documents/events/20090309Panama/Documents/UN-REDD\%20 PNG\%20NJPD.pdf (28 October 2010).

Climate, Community and Biodiversity Alliance (CCBA) 2010a CCB projects. http://www.climate-standards.org/projects/index.html (31 August 2010).
Climate, Community and Biodiversity Alliance (CCBA) 2010b Comments received by the CCBA during the validation audit - Project: Kamula Doso Improved Forest Management Carbon Project: Climate, Community and Biodiversity Alliance. http://www.climate-standards.org/projects/index.html (31 August 2010).

Department of Environment and Conservation (DEC) 2009 Media statement: forest carbon trading. The National, 31 August 2009.

Filer, C. 2011 The new land grab in Papua New Guinea. Paper given at International conference on Global Land Grabbing. Institute of Development Studies (UK). 6-8 April.

Filer, C., Keenan, R.J., Allen, B.J. and McApline, J.R. 2009 Deforestation and degradation in Papua New Guinea. Annals of Forest Science 66(8): 813-825.

Forest Trends 2006 Logging, legality and livelihoods in PNG: synthesis of official assessments of the large-scale logging industry (Volumes 1 and 2). Forest Trends, Washington, DC.

Fox, J.C., Yosi, C.K., Nimiago, P., Oavika, F., Pokana, J.N., Lavong, K., Keenan, R.J. 2010 Assessment of aboveground carbon in primary and selectively harvested tropical forest in Papua New Guinea. Biotropica 42(4): 410-419.

Global Canopy Programme (GCP) 2008 The little REDD book: A guide to governmental and non-governmental proposals for reducing emissions from deforestation and degradation. Global Canopy Programme, Oxford, UK.

Government of Papua New Guinea (GoPNG) 1989 Report of the Commission of inquiry into aspects of the timber industry in Papua New Guinea (The Barnett Report). Department of the Prime Minister. Waigani, Papua New Guinea.

Government of Papua New Guinea (GoPNG) 2010 Climatecompatible development for Papua New Guinea. Port Moresby, Papua New Guinea.

Gridneff, I. 2009a Carbon conmen selling the sky. Sydney Morning Herald, 13 June.

Gridneff, I. 2009b PNG's PM nephew 'pushing carbon deals'. The Age, 3 July.

Howes, S. 2009 Cheap but not easy: the reduction of greenhouse gas emissions from deforestation and forest degradation in Papua New Guinea. Pacific Economic Bulletin 24(1): 13.

INA and IGES 2010 Summary of PNG situation assessment for REDD. Presentation at the REDD Capacity Building Workshop and Building Consensus, Gaire, Central Province, Papua New Guinea, 1-3 March. Institute of National Affairs and Institute for Global Environmental Strategies.

International Tropical Timber Organisation (ITTO) 2007 Achieving the ITTO objective 2000 and sustainable forest management in Papua New Guinea: Report of the diagnostic mission. International Tropical Timber Organisation. http://www.itto.or.jp/ live/Live_Server/3632/E-C42-7_PNG_Mission_Full_Report.doc (1 August 2010).

Lang, C. 2010 Papua New Guinea plans to scrap REDD safeguards. REDD-Monitor. http://www.redd-monitor.org/2010/06/11/ papua-new-guinea-plans-to-scrap-redd-safeguards/ (1 July 2010).

Ministry of Forests 2009 Forestry and climate change framework for action. Ministry of Forests, Port Moresby, Papua New Guinea. 
Overseas Development Institute (ODI) 2007a What can be learnt from the past? A history of the forestry sector in Papua New Guinea. Overseas Development Institute, London.

Overseas Development Institute (ODI) 2007b Issues and opportunities for the forest sector in Papua New Guinea. Overseas Development Institute, London.

Office of Climate Change and Development (OCCD) 2011 UN collaborative programme on reducing emissions from deforestation and forest degradation in developing countries (UN-REDD): National Programme Document. Office of Climate Change and Development, Port Moresby, Papua New Guinea. Office of Climate Change and Environmental Sustainability (OCCES) undated National climate change policy framework for Papua New Guinea. Office of Climate Change and Environmental Sustainability, Waigani, Papua New Guinea.

Papua New Guinea Eco-Forestry Forum (PNGEFF) 2010 PNGEFF's comments and conditional endorsement for the PNG National Joint Program to the UNREDD Policy Board. Papua New Guinea Eco-Forestry Forum, Port Moresby, Papua New Guinea.

Papua New Guinea Forestry Authority (PNGFA) 2011 Safeguarding the resource base: state of Papua New Guinea's forest and land. Paper presented at the Institute of National Affairs and Institute for Global Environmental Strategies REDD+, PES and Benefit Sharing workshop. Port Moresby, Papua New Guinea, 17-18 February. http://www.inapng.com/pdf_files/Goodwill\%20 Amos\%20-\%20PNGFA.pdf (May 2011).

Shearman, P.L., Bryan, J., Ash, J., Hunnam, P., Mackey, B. and Lokes, B. 2008 The state of the forests of Papua New Guinea: mapping the extent and condition of forest cover and measuring the drivers of forest change in the period 1972-2002. University of Papua New Guinea, Port Moresby, Papua New Guinea.

Shearman, P. L., Ash, J., Mackey, B., Bryan, J. E., and Lokes, B. 2009 Forest conversion and degradation in Papua New Guinea 1972-2002. Biotropica 41(3): 379-390.
Shearman, P., Bryan, J., Ash, J., Mackey, B. and Lokes, B. 2010 Deforestation and degradation in Papua New Guinea: a response to Filer and colleagues, 2009. Annals of Forest Science 67(3): 300-304.

Shearman, P. and Bryan, J. 2011 A bioregional analysis of the distribution of rainforest cover, deforestation and degradation in Papua New Guinea. Australian Ecology 36(1): 9-24.

Somare, M. 2009 Parliamentary statement: carbon trading and Office of Climate Change and Environmental Sustainability. The National, 5 August.

Taylor, R. 1997 The state versus custom: regulating Papua New Guinea's timber industry. In: Filer, C. (ed.) The political economy of forest management in Papua New Guinea. National Research Institute, Boroko, Papua New Guinea.

Wertz-Kanounnikoff, S. and Kongphan-Apriak, M. 2009 Emerging REDD+: a preliminary survey of demonstration and readiness activities. CIFOR Working Paper No. 46. CIFOR, Bogor, Indonesia.

World Bank 2006 Papua New Guinea forest and conservation project: note on cancelled operation (PE-4398/GE4345). Rural Development and Natural Resources Sector Unit, East Asia and Pacific Region. http://www-wds.worldbank.org/external/default/ main?pagePK=64193027\&piPK=64187937\&theSitePK $=523679 \& \mathrm{~m}$ enuPK $=64187510 \&$ searchMenuPK=64187283\&siteName=WDS\&e ntitylD=000090341_20061122103441 (10 September 2010).

Wynn, C. and Creagh, S. 2009 Carbon markets showing cracks. Reuters, 4 June.

\section{Acknowledgements}

I would like to thank Phil Shearman, Jane Bryan, Rodney Keenan, Peter Dam and Nalau Bingeding for providing additional information and clarification of data, and Maria Brockhaus and Andrew Wardell for valuable comments on previous drafts.

\section{然}

NORWEGIAN MINISTRY OF THE ENVIRONMENT NORWEGIAN MINISTRY OF FOREIGN AFFAIRS

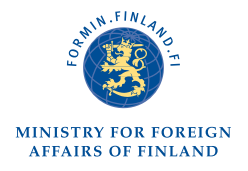

AusAID
DFID

Department for International Development

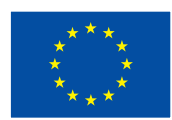

\section{the David Lucile Packard FOUNDATION}

USAID

FROM THE AMERICAN PEOPLE

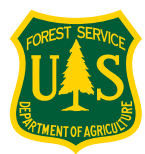

